\title{
Analyzing Islamic Micro Finance Performance with Economic Value Added (EVA): Learning from Baitul Wat Tamwil (BMT) Usaha Gabungan Terpadu Sidogiri Indonesia
}

\author{
Titik Inayati, Bambang Subroto, Achmad Fachan \& Atim Djazuli \\ Doctoral Program of Management \\ Brawijaya University of Malang, Indonesia \\ E-mail: titikinna_roesdiyana@yahoo.co.id
}

Received: August 7, 2014 Accepted: October 16, 2014 Published: November 3, 2014

doi:10.5296/bmh.v2i2.6103 URL: http://dx.doi.org/10.5296/bmh.v2i2.6103

\begin{abstract}
Analyzing Islamic Micro Finance Performance with Economic Value Added (EVA). EVA analysis is used for deciding the regulations of investment of BMT. Monetary report is analyzed with EVA, Net Operating Profit after Tax (NOPAT), Weighted Average Cost of Capital (WACC), and Invested Capital.

The result of performance using EVA shows that BMT can create value. NOPAT underwent a significant increase compare with the capital fund. The profit that is created is higher than accounting profit which shows that BMT has a very good performance. The capital which is consists of debt and equity has been used efficiently and effectively so that it can increase the profit. The BMT officer should pay attention to the financial performance in order to decide the regulation and investment that will be done. Investment and activity which is done by BMT should be resulted more value so that it can give the real profit for the development of BMT.
\end{abstract}

Keywords: EVA, NOPAT, WACC, Invested Capital 


\section{Importance of EVA for Analysing Islamic Micro Finance Performance}

Several previous studies that measure many aspects of the financial performance of the company. Ismail (2010) in a study analyzing the performance of Islamic Bank with financial ratios to assess earnings performance, asset quality, capital adequacy and Islamic banking. The information used to generate the ratio seen from the income statement and balance sheet banking. Financial ratios are generally still an important measure in assessing the performance of the company. Ruky (2002: 43) states measured performance using financial ratios and the ability to generate a rate of return on investment. The company's performance is measured by returns to labor, labor efficiency and return to the proprietor, so that the performance of the company is the result of the overall management decisions are carried out continuously. Suffian and Noor (2009), Benamraoui (2008), Siddiqui (2008), Rosly and Burn (2003) conducted a study on Islamic Banking's financial performance based on financial analysis. Furthermore, Wiyono and Rahmayuni (2010) also noted the importance of financial analysis to measure the success of the performance of Islamic Banking. Financial analysis will facilitate banks to calculate the return on assets, equity, and adequate liquidity.

The measurement of financial performance can be done by using many kinds of analyzing method. One of them is by using economic value added (EVA). EVA is a new method which is measuring the value from a corporation by counting the capital that is sometimes being ignored in a measurement of profit. EVA is a measuring method in which measure that happens in a corporation by considering the capital which value gained can cover all the operational cost and its capital (Stewart, 1997; Davies, 2001).

One of the advantage of EVA is, it can give a description of the added value that the corporation gained by considering the whole capital cost included debt and equity cost. That added value has a close relationship with the fulfillment of the needed of stakeholders toward the return of capital that has been given to the corporation (Stewart, 1997).

Young and O’Byrne stated that EVA has to be maximized by the manager if they would like to arrange a strategy in the future. EVA in relation with the allocation of capital is providing strong incentive for the manager to look for and to implement investment that can create value. EVA's target can also be shifted to the division and department (Young \& O'Byrne, 2000).

Baitul Maal Wat Tamwil (BMT) is one of the non-bank organizations which run its business based on the Islamic syariah. Based on Imaniyati (2010: 75), "BMT is people's economic organization which has duty to develop productivity and investment with the balance-share result in order to increase economic quality of small business to decrease poverty”. BMT has two roles, those are as Baitul Maal and Baitul Tamwil, and those two roles have a relationship with the function of BMT to increase the quality of micro business.

At the date of February 22, 2013 BMT Usaha Gabungan Terpadu awarded as The Best Islamic Micro Finance in Islamic Finance Award and Cup 2013 in Jakarta. Earned awards for his achievements in developing Sharia Microfinance Institutions. The development of assets, turnover, profit and BMT Usaha Gabungan Terpadu influenced by the success of the 
business units that run in all branches. Until 31 December 2013 BMT Usaha Gabungan Terpadu has had three (3) business units as follows: (1) The business unit in the field of Islamic financial services. In this unit there are several types of products, namely financial services: Deposit, Financing and Receivables. Deposits Unit consists of: Sharia Deposits, Savings Deposits Mudharobah, Hari Raya Savings, Savings Sacrifice Worship, Walimah Savings, Savings Aqiqah, Education Plus Savings, Savings Pilgrimage / Tourism, Hajj and Savings Deposits Umrah. Financing and receivables consist of: (1) Mudharabah, Murobahah, Musharaka, Bai 'Bitsamanil Ajil, Ijarah Rahn and, (2) Services and pomegranate transfer services, (3) Counters online payment through Bank, (4) Unit of service BMT and (5) ZIS (Zakat, Sadaqah Donation).

BMT is also has one more principle, that is profit sharing. It is according to the statement of PINBUK that says the basic of muamalah relationship in Islam is mutualism relationship, which means the interest that reflects exploitation replaced with balance-share, it is fair, cooperation, and it can prevent someone from social, economy, and immaterial difficulty. Syariah financial organization consist of syariah financial itself and non-syariah financial organization like BMT (PINBUK, 2010: 25).

Generally, the measurement of financial condition like in BMT is still use ratio analysis that is not considering the capital of it. While the added value needs the capital in its counting. Measuring using EVA method will help BMT in measure the added value.

\section{Objectives}

Financial analysis of BMT Usaha Gabungan Terpadu Sidogiri in East java Province of Indonesia.

- Knowing the added value of BMT Usaha Gabungan Terpadu Sidogiri in East java Province of Indonesia.

- $\quad$ Knowing the equity cost

- Knowing the capital calculation.

\section{Methodology}

This research is done by using secondary data, it is financial report that gained from data BMT Usaha Gabungan Terpadu (UGT) Sidogiri. The financial report is used to calculate economic value added (EVA). EVA can be used to measure the added value and the financial condition of BMT UGT Sidogiri. The EVA calculation used Net Operating Profit After Tax (NOPAT), Weight Average Cost Of Capital (WACC), Invested Capital.

\section{History of Bmt Usaha Gabungan Terpadu Sidogiri in East Java Province of Indonesia}

Baitul Maal Wat Tamwil Usaha Gabungan Terpadu next in say BMT UGT Sidogiri is one of the non-bank financial organizations in the form of cooperation. BMT has two core businesses; those are Baitul Maal and Baitul Tamwil. BMT as Baitul Maal is a financial organization that receives and manages social funds such as zakat, infaq, shodaqoh, etc. BMT as Baitul Tamwil is a financial organization that manages its member's fund or society in the 
form of saving and costing, these activities is focused to increase the micro business so that it will be more productive.

BMT UGT Sidogiri started at June 6, 2000 and it was located in Surabaya. The legalization of BMT UGT Sidogiri has been done by the The Head Office of the Departement of co-operatives Micro Small and Madium in Province East Java in July 22, 2010 with Surat Keputsan Nomor: 09/BH/KWK.13/VII/2000. BMT UGT Sidogiri was built by some people from teachers of boarding schools Sidogiri that includes some teachers and the head of madrasah, some alumnus of Pondok Pesantren Sidogiri and the volunteers in East Java. BMT UGT Sidogiri nowadays has 192 Unit Service BMT and a unit of transfer service. The income of BMT UGT Sidogiri in 2013 is Rp 3.1 Trillions with the achievement is Rp 622 Billions.

At the first time, BMT Maslahah Mursalah lil Ummah (BMT MMU) service office was rented with $16 \mathrm{~m}^{2}$ huge and the capital is $\mathrm{Rp} 13.500 .000$ which had been collected from 148 members. In July $22^{\text {nd }} 2000$, BMT UGT Sidogiri in Jalan Asem Mulyo 48 C Surabaya has been launched. Naming UGT (Usaha Gabungan Terpadu) in BMT UGT Sidogiri based on fact that most of the founders of that organization are Pesantren or Madrasah that are included in Urusan Guru Tugas Pondok Pesantren Sidogiri.

\section{Products of BMT UGT Sidogiri}

In running the business, BMT UGT Sidogiri has three units business. BMT is a business that focuses on syariah financial product while focusing on the profit. The products are:

(1) Saving: (a) Syariah Saving, this is a saving that can be given and withdrawn all the time by using the covenant wadi'ah Ad Dhamanah, (b) Period Saving, this saving can be with drawn based on the time that has been agreed, whether this is 3, 6 months or others based on the covenant mudharabah, (c) Idul Fitri Saving, this saving is intended to welcome idul fitri, the withdrawal once in a year near idul fitri or o a month before idul fitri, (d) Qurban saving, this saving is intended to strengthen the will for doing qurban. The withdrawal can be done only by the time idul adha approaching or a month before it comes, (e) Walimah Saving, this saving is intended to cost walimah (marriage) and its withdrawal can be done only near the marriage or events like this, (f) Education Saving Plus, this saving is used to cost the education. The withdrawal can be done if there is a need to cost something based on the agreement, (g) Ziarah Saving, this saving is intended to ziarah and its with drawal can be done by the agreement among the saver, (h) Aqiqoh Saving, this saving is intended to aqiqoh. The withdrawal can be done all the time based on the agreement, (i) Hajj Saving (Al Haramain), this saving is used to help people who want to do hajj by using covenant wadi'ah ad dhamanah. The with drawal can be done near the departure of hajj.

(2) Loan (a) Mudharabah (profit sharing), this loan is fully done by BMT and the customers just provide the business and its management. The benefits and loss will be shared based on the covenant and the result, (b) Mudharabah (Sell and Buy) is funding the sell and buy activity which the payment is done in the deadline and its completion and the profit based on the covenant, (c) Musyarakah, A joint enterprise or partnership structure with profit/loss 
sharing implications that is used in Islamic finance instead of interest-bearing loans. Musharakah allows each party involved in a business to share in the profits and risks. Instead of charging interest as a creditor, the financier will achieve a return in the form of a portion of the actual profits earned, according to a predetermined ratio. However, unlike a traditional creditor, the financier will also share in any losses. (d) Ba'i Bitsamanil Ajil, Bai' bithaman ajil, which is a type of deferred payment sale, is a sale of goods on a price where the payments will be deferred. This includes a profit margin that is agreed upon by both parties in this type of Islamic finance. A Bai' bithaman ajil is used under a type of facility that deals with Islamic finance. The deferred payment of interest can be avoided since the customer will pay the sale price and that differs from interest that is charged on a loan. The bringing together of two financial transactions is not allowed under the shariah (Islamic law). Basically in a Bai' bithaman ajil there is interest charged that looks much like a sale. (e) Qordul Hasan, is the loan that given to the member of BMT that seems to be deserved to get it. (f) Qord Bil Ijarah is the funding that is done by keeping one of the property of the borrower.

(3) Transfer Service. This is aimed to ease the santri of Pondok Pesantren Sidogiri in accepting and transferring money. This kind of service has been cooperating with some others financial institutions like Bank Central Asia Syariah to ease the process of transferring the money.

(4) ZIS (Zakat, Infaq, and Shadaqah), this is an implementation of Baitul Maal which is the orientation in social. ZIS is accepting and managing the zakat fund, infaq, and shadaqah and to deliver it to mustahik (those who deserve to get it) whether it is consumptive or productive.

\section{The Result of the Research}

\subsection{Calculating NOPAT}

Table 1. Calculation of NOPAT BMT UGT Sidogiri from 2011, 2012 and 2013 (in rupiahs)

\begin{tabular}{llll}
\hline Components of NOPAT & $\mathbf{2 0 1 1}$ & $\mathbf{2 0 1 2}$ & $\mathbf{2 0 1 3}$ \\
\hline Profit before tax and Zakat & 11.582 .784 .649 & 18.009 .915 .002 & 32.716 .977 .343 \\
Cost for The Result & 8.840 .921 .482 & 17.358 .761 .112 & 30.948 .005 .207 \\
NOPAT & 20.423 .706 .131 & 35.368 .676 .114 & 63.664 .982 .550 \\
\hline
\end{tabular}

Source: BMT UGT Sidogiri data.

Based on the calculation of NOPAT in table 1, it shows that NOPAT in 2011 is Rp. 20.423.706.131 and there is a significance increase in 2012, it is $73.1 \%$ become $\mathrm{Rp}$. 35.368.676.114. This increasing happens because of profit increasing before tax and zakat of 2012 is Rp. 6.427.130.353. While the load of profit sharing has been increasing as amount of 96.3\% in 2012. In 2013, NOPAT has increased very significant become Rp. 63.664.982.250. This increasing because of the profit after tax and zakat, this is Rp. 14.707.062.341 from 
2012. The load of profit sharing has been increasing from Rp. 17.358.761.112 in 2012, become Rp. 30.948.005.207 in 2013.

6.2 Calculating the Debt

Table 2. Calculation of the Debt Cost BMT UGT Sidogiri from 2011, 2012 and 2013 (in rupiahs)

\begin{tabular}{llll}
\hline Components of The Debt Cost & $\mathbf{2 0 1 1}$ & $\mathbf{2 0 1 2}$ & $\mathbf{2 0 1 3}$ \\
\hline Cost for The Result & 8.840 .921 .482 & 17.358 .761 .112 & 30.948 .005 .207 \\
Debt Total & 178.823 .404 .695 & 283.054 .711 .274 & 440.972 .579 .710 \\
The Cost of Debt before Tax and Zakat $\left(\mathrm{K}_{\mathrm{b}}\right)$ & 0.049 & 0.061 & 0.070 \\
Tax and Zakat & 1.321 .805 .130 & 1.913 .321 .230 & 2.975 .584 .926 \\
Profit before tax and Zakat & 12.904 .589 .779 & 19.923 .236 .232 & 35.692 .562 .269 \\
$\mathrm{t}$ & 0.102 & 0.096 & 0.083 \\
$(1-\mathrm{t})$ & 0.898 & 0.904 & 0.917 \\
The Cost of Debt before Tax and Zakat $\left(\mathrm{K}_{\mathrm{d}}\right)$ & 0.044 & 0.055 & 0.064 \\
\hline
\end{tabular}

Source: Rapat Anggota Tahunan BMT UGT Sidogiri.

Debt in 2011 is 0,044 or $4.4 \%$, and there is an increasing become 5.5\% in 2012. It happens because there is a fee in profit sharing and the total of debt, this is Rp. 8.517.839.630 and Rp.104.231.306.579. While the tax and zakat have also increased $44.7 \%$ and $54.3 \%$ from 2011. In 2013, the debt counted as 6.4\%and the debt fee in 2013 has increased from 2012 that is $5.5 \%$. It happens because the cost of profit sharing has been increased become Rp.30.948.005.207and the total of debt has been increased become Rp.440.972.579.710 in 2013. The tax and the zakat and also profit before tax and zakat has been counted getting increasing as Rp.1.062.263.696 and Rp.15.769.326.037.

\subsection{Calculating Equity}

Table 3. Calcultion of the Equity Cost BMT UGT Sidogiri from 2010, 2011 and 2012 (in rupiahs)

\begin{tabular}{llll}
\hline Components of The Equity Cost & $\mathbf{2 0 1 1}$ & $\mathbf{2 0 1 2}$ & $\mathbf{2 0 1 3}$ \\
\hline Net Profit after Taxation and Zakat & 11.582 .784 .649 & 18.009 .915 .002 & 32.716 .977 .343 \\
Equity Total & 33.575 .680 .000 & 47.374 .040 .000 & 85.763 .260 .000 \\
Equity Cost & 0.034 & 0.038 & 0.038 \\
\hline
\end{tabular}

Source: BMT UGT Sidogiri Data. 


\section{Macrothink}

Business and Management Horizons

ISSN 2326-0297

2014, Vol. 2, No. 2

Equity in 2011 is $3.4 \%$ and it has been increased 0.038 in 2012 with the amount Rp.6.427.130.35. The total equity in 2013 is $41 \%$. There is no equity increase in 2013, it happens because profit after tax and zakat has been increased become 32.716.977.343 together with the total equity, it is $81 \%$.

\subsection{Calculating WACC}

Table 4. Calculations of WACC BMT UGT Sidogiri from 2011, 2012 and 2013 (in rupiahs)

\begin{tabular}{llll}
\hline Components of WACC & $\mathbf{2 0 1 1}$ & $\mathbf{2 0 1 2}$ & $\mathbf{2 0 1 3}$ \\
\hline Debt & 178.823 .404 .695 & 283.054 .711 .274 & 440.972 .579 .710 \\
Debt Total and Equity & 212.399 .084 .695 & 330.428 .751 .274 & 526.635 .839 .710 \\
Debt Procentage /Total & 0.842 & 0.857 & 0.842 \\
$\mathrm{~K}_{\mathrm{d}}$ & 0.044 & 0.055 & 0.064 \\
& 0.037 & 0.047 & 0.053 \\
Equity & 33.575 .680 .000 & 47.374 .040 .000 & 85.763 .260 .000 \\
Debt Total and Equity & 212.399 .084 .695 & 330.428 .751 .274 & 526.635 .839 .710 \\
Equity Procentage / Total & 0,158 & 0,143 & 0,163 \\
K & 0,034 & 0,038 & 0,038 \\
& 0,005 & 0,005 & 0,006 \\
WACC & 0,042 & 0,052 & 0,059 \\
\hline
\end{tabular}

Source: BMT UGT Sidogiri Data.

The average of WACC BMT in 2011 is 4.2\%. In 2012 has been increased 1\% become 5.2\%. In 2013 WACC BMT become 5.9\% and it has been increased even just $0.7 \%$. From the explanation above, we know that WACC has been increased annually. It happens because the increase of the cost of the debt and the equity cost from year to year can harm the BMT in gaining the positive EVA.

\subsection{Calculating Invested Capital}

Table 5. Calculation Invested Capital BMT - UGT Sidogiri from 2011, 2012 dan 2013 (in rupiahs)

\begin{tabular}{llll}
\hline Components of the invested capital & $\mathbf{2 0 1 1}$ & $\mathbf{2 0 1 2}$ & $\mathbf{2 0 1 3}$ \\
\hline Long-term Liabilities and Short-term & 178.823 .404 .695 & 283.054 .711 .274 & 440.972 .579 .710 \\
Equity & 33.575 .680 .000 & 47.374 .040 .000 & 85.763 .260 .000 \\
The Total of Capital & 212.399 .084 .695 & 330.428 .751 .274 & 526.635 .839 .710 \\
\hline
\end{tabular}

Source: BMT UGT Sidogiri Data. 
The total of capital from 2011 to 2013 is increased. In 2012 there is 5,5\% increasing become Rp.330.428.751.274 from 2011. In 2013, invested capital increased Rp.196.207.088.436 become Rp.526.635.839.710 from 2012.

6.6 Calculating EVA

Table 6. Calculation EVA BMT UGT Sidogiri from 2011, 2012 and 2013 (in rupiahs)

\begin{tabular}{llll}
\hline Components of EVA & $\mathbf{2 0 1 1}$ & $\mathbf{2 0 1 2}$ & $\mathbf{2 0 1 3}$ \\
\hline NOPAT & 20.423 .706 .131 & 35.368 .676 .114 & 63.664 .982 .550 \\
WACC & 0,042 & 0,052 & 0,059 \\
Invested Capital & 212.399 .084 .695 & 330.428 .751 .274 & 526.635 .839 .710 \\
(WACC x Invested Capital) & 8.920 .761 .557 & 17.182 .295 .066 & 30.071 .514 .542 \\
EVA & 11.496 .002 .368 & 17.799 .280 .665 & 33.311 .090 .211 \\
\hline
\end{tabular}

Source: BMT UGT Sidogiri Data.

BMT has successfully created EVA Rp.11.496.002.368 in 2011. It means that BMT has successfully satisfied the stakeholder. In 2012, EVA is increased $54.8 \%$ from 2011, it happens because NOPAT is $73 \%$ while the cost of capital is $92,6 \%$ can be covered by the profit that has been created by BMT. In 2013, NOPAT increased 80\%, or from Rp. 35.368.676.114 to 63.664.982.550. The increase of capital cost Rp.12.889.219.476 or $75 \%$ in 2012 can be covered by the profit of BMT.

In 2011, the accounting profit of BMT is Rp.11.582.784.649; it is from the calculation of EVA in 2011 that is Rp.11.496.002.368. In 2012, the accounting profit of BMT is Rp.18.009.915.002, it is from the calculation of EVA in 2012 that is Rp.17.779.280.665. The economic value of EVA in 2011 and 2012 is lower than accounting profit because it should be decreased with the capital cost. In 2013, accounting profit is Rp.32.716.977.343, it is increased comparing with the economical profit, that is Rp.33.311.090.211, it is because the increase of NOPAT, that is $80 \%$

\section{Conclusion}

The result of the analysis toward the financial performance in BMT UGT Sidogiri using EVA is, in 2011 and 2012, BMT UGT Sidogiri had resulted the positive EVA and it can be concluded that BMT UGT resulted the added value to the corporation. It shows that the financial performance of BMT is good so that the cost can be covered with NOPAT. Thus, the EVA is still low comparing with the accounting profit in BMT.

In 2013, BMT UGT Sidogiri resulted the positive score in the calculation of EVA so it can be concluded that BMT could create an added value. It happens because NOPAT had a significance increase comparing with the capital cost. This increasing shows that BMT UGT Sidogiri has a very good performance. The capital cost in the form of the debt and equity cost has been used effectively and efficiently so that it can create the increase of profit. 


\section{References}

Benamraoui, A. (2008). Islamic Banking: The Case of Algeria. Journal of Islamic and Middle Eastern Finance and Management. Algeria. http://dx.doi.org/10.1108/17538390810880973

Davies, M. (2001). Value-Based management: The Theory and the Practise. Finance and Management.

Imaniyati, N. S. (2010). Aspek-Aspek Hukum Baitul Maal wat Tamwil. PT. Citra Aditya Bakti. Bandung.

Ismail, A. G. (2010). Money, Islamic Banks and the Real Economy. Cengage Learning Asia Pte Ltd. UIC Building. Singapore

PINBUK. (2010). Modul Pelatihan Manager. Pusat Inkubasi Bisnis Usaha Kecil. Tulungagung. Jawa Timur.

Rosly, S. A., \& dan Burn, M. A. (2003). Performance of Islamic and Mainstream Banks in Malaysia. Emerald Internasional Journal of Social Economics. http://dx.doi.org/10.1108/03068290310500652

Ruky, A. S. (2002). Sistem Manajemen Kinerja. PT. Gramedia Pustaka Utama. Jakarta.

Siddiqui, A. (2008). Financial Contracts, Risk and Performance of Islamic Banking. Emerald Group Publishing Limited.

Stewart, S. (1997). The ECA Company. Stern Stewart\& Co.

Suffian, F., \& dan Noor, M. (2009). The Determinants of Islamic Banks’ Efficiency Changes Empirical Evidence from the MENA and Asian Banking Sectors. Journal of Islamic and Middle Eastern Finance and Management. http://dx.doi.org/10.1108/17538390910965149

Undang-Undang Republik Indonesia No. 17. (2012). Undang-Undang Perkoperasian 2012. Redaksi Sinar Grafika. Jakarta.

Wiyono, S. K., \& dan Rahmayuni, S. (2010). The Effect of Credit Risk to Islamic Bank Profitability with Islamic Income and Profit Sharing Ratio as Moderating Variable. School of Business and Management Institut Teknologi Bandung. Bandung.

Young, S. D., \& dan O’Byrne, S. (2000). EVA and Value-Based Management: A Practical Guide to Implementation. McGraw-Hill.

\section{Copyright Disclaimer}

Copyright for this article is retained by the author(s), with first publication rights granted to the journal.

This is an open-access article distributed under the terms and conditions of the Creative Commons Attribution license (http://creativecommons.org/licenses/by/3.0/). 